\title{
ROUGHNESS FACTOR IN OVERTOPPING ESTIMATION
}

\author{
Josep R. Medina ${ }^{1}$ and Jorge Molines ${ }^{2}$
}

\begin{abstract}
The roughness factor $\left(\gamma_{\mathrm{f}}\right)$ is a key variable to estimate wave overtopping discharge on mound breakwaters. In this study, the $\gamma_{\mathrm{f}}$ is re-calibrated using a dataset extracted from the CLASH database. Compared to previous roughness factors calibrated using less restrictive data, overtopping estimators with a few explanatory variables showed variations up to $15 \%$ in the $50 \%$ percentile of $\gamma_{\mathrm{f}}$. On the contrary, the CLASH neural network overtopping predictor showed insignificant variations in the roughness factor, since it is less sensitive to the variability in the data used for calibration. The confidence interval width of the CLASH neural network was narrow compared to simple explicit overtopping estimators, given that it is less sensitive to the number of data used for calibration. The $\gamma_{\mathrm{f}}$ values used to estimate wave overtopping discharge should be carefully calibrated, especially when using simple empirical formulas.
\end{abstract}

Keywords: mound breakwater; overtopping; roughness factor; armor unit

\section{INTRODUCTION}

Overtopping on mound breakwaters is usually a key design factor affecting breakwater crest elevation, construction cost and environmental impact. Overtopping rates depend on a variety of structural and environmental characteristics. This study focuses attention on the roughness factor $\left(\gamma_{\mathrm{f}}\right)$ generally associated to the armor unit geometry, number of layers and placement type; the higher the roughness factor, the higher the overtopping rates.

During the last four decades, the roughness factor has been proposed as a parameter to consider the performance of different armoring systems, especially in regard to run-up and overtopping. After crest freeboard $\left(R_{c}\right)$ and incident significant wave height $\left(H_{m 0}\right)$, the roughness factor $\left(\gamma_{f}\right)$ is the third most common parameter used to estimate overtopping rates on mound breakwaters. Van der Meer and Janssen (1994) proposed Eq. [1] to estimate overtopping rates on dikes in non-breaking conditions:

$$
Q_{V M J}=\frac{q}{\sqrt{g \cdot H_{m 0}^{3}}}=A \cdot \exp \left(-B \cdot \frac{R_{c}}{H_{m 0}} \cdot \frac{1}{\gamma_{f}}\right)
$$

where $A=0.2, B=2.6$ and $\gamma_{f}=$ roughness factor. Numerous formulas have been proposed to estimate overtopping rates on mound breakwaters; most of them include the use of $\gamma_{\mathrm{f}}$ to take into account the specific armoring system. For instance, one of the independent input variables in the CLASH overtopping neural network (CLASH-NN), downloaded from Deltares (2017), is the roughness factor taken from Molines and Medina (2015); a different $\gamma_{\mathrm{f}}$ list given by Coeveld et al. (2005) was originally used within the CLASH project. Fig. 1 shows the cross section and the 15 input variables considered for CLASH-NN.

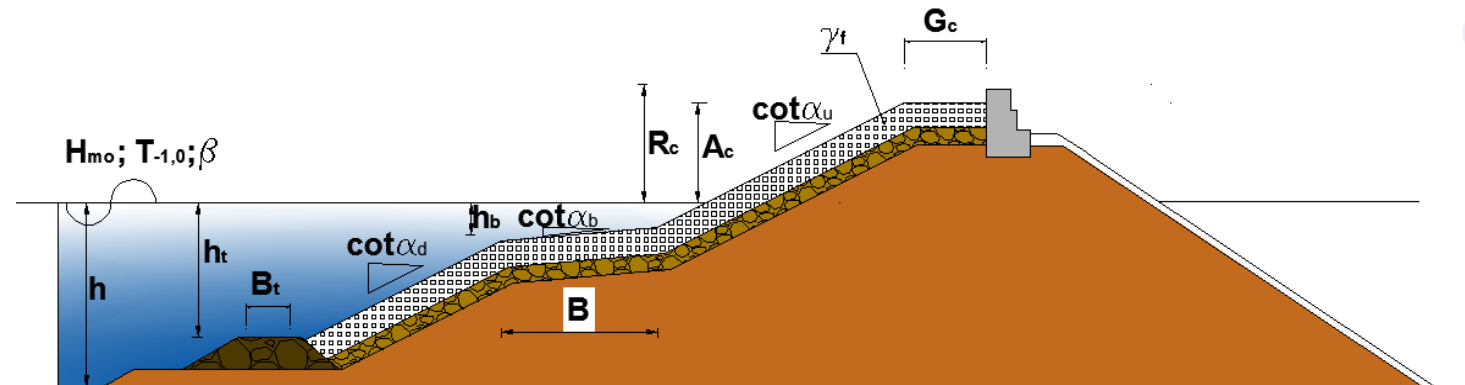

Figure 1. Breakwater cross section considered by CLASH-NN.

There are several lists of roughness factors given in the literature, but these do not always provide the same value for the same armoring system (see Table 1); for instance, the $\gamma_{\mathrm{f}}$ proposed for rock (2layer) by Coeveld et al. (2005) and EurOtop (2007) were $\gamma_{\mathrm{f}}=0.50$ and 0.40, respectively. Van der Meer and Bruce (2014) proposed new revised formulas for low and very low crest freeboards $\left(\mathrm{R}_{\mathrm{c}} / \mathrm{H}_{\mathrm{m} 0}<0.8\right)$

\footnotetext{
${ }^{1}$ Department of Transportation, Universitat Politècnica de València, Camino de Vera s/n, 46022 Valencia, Spain

2 Department of Transportation, Universidad Politécnica de Cartagena, Paseo Alfonso XIII 52, 30203 Cartagena, Spain
} 
using the same roughness factors as those given in EurOtop (2007). Bruce et al. (2009) made changes in the $\gamma_{\mathrm{f}}$ proposed by Bruce et al. (2006) and calculated the confidence intervals.

As highlighted by Molines and Medina (2015), given a breakwater and a specific overtopping predictor (e.g. formula, neural network model, etc.), the roughness factor is the parameter which takes into consideration how overtopping is influenced by all structural variables not explicitly included in the predictor. For instance, armor thickness, armor unit geometry and placement, filter and core permeability, crest berm width and other structural characteristics are not included in Eq. [1]; however, they are implicitly considered by the roughness factor $\left(\gamma_{\mathrm{f}}\right)$ used in Eq. [1].

Smolka et al. (2009) proposed Eq. [2] to estimate overtopping rates for conventional cube and Cubipod armored breakwaters with high crown walls $\left(R_{c}>A_{c}\right)$; recommended roughness factors were $\gamma_{\mathrm{f}}=0.50,0.46$ and 0.44 for double-layer cube and single- and double-layer Cubipod armoring, respectively.

$$
Q_{S Z M}=\frac{q}{\sqrt{g \cdot H_{m 0}^{3}}}=A \cdot \exp \left(D \cdot \operatorname{Irp}-C \cdot \frac{A_{c}}{R_{c}}-B \frac{R_{c}}{H_{m 0}} \cdot \frac{1}{\gamma_{f}}\right)
$$

where $\mathrm{A}=0.20, \mathrm{~B}=2.16, \mathrm{C}=3.27, \mathrm{D}=0.53$ and $\gamma_{\mathrm{f}}=$ roughness factor.

Molines and Medina (2016) proposed Eq. [3] to emulate the CLASH-NN with an explicit relationship between input explanatory variables and overtopping rates. The authors used the methodology described previously by Molines and Medina (2015) to provide specific lists of calibrated $\gamma_{\mathrm{f}}$ to be used together with their corresponding overtopping estimator (see Table 1).

$$
\begin{aligned}
& Q=\left(\frac{q}{\sqrt{g \cdot H_{m 0}^{3}}}\right)=Q 6=\exp \left(\lambda_{2} \cdot \lambda_{3} \cdot \lambda_{4} \cdot \lambda_{5} \cdot \lambda_{6}\left[-1.6-2.6 \cdot \frac{R_{c}}{H_{m 0}} \cdot \frac{1}{\gamma_{f} \gamma_{\beta}}\right]\right) \\
& \lambda_{2}=1.20-0.05 \cdot\left(\operatorname{Ir} \sqrt{R_{c} / H_{m 0}}\right) \\
& \lambda_{3}=1.0+2.0 \cdot \exp \left(-35 \cdot R_{c} / h\right) \\
& \lambda_{4}=\max \left[0.95 ; 0.85+0.13 \cdot G_{c} / H_{m 0}\right] ; \\
& \lambda_{5}=0.85+0.15 \cdot A_{c} / R_{c} \quad \text { if } \quad \text { Bt }=0 \\
& \lambda_{6}=\left\{\begin{array}{cc}
\max \left[1.0 ;\left(1.2-0.5 \cdot R_{c} / h\right)\right] \quad \text { if } \quad B t>0 \\
1.0 & \text { for long }- \text { crested waves }
\end{array} \text { valid for } \beta \leq 60^{\circ}\right.
\end{aligned}
$$

where $\operatorname{Ir}=T_{-1,0} / \cot \alpha\left[2 \pi \mathrm{H}_{m 0} / g\right]^{1 / 2}$ and $R_{c}, A_{c}, G_{c}$, $h$ and $B_{t}$ are defined in figure 2 .

Nevertheless, the roughness factor is still a convenient parameter to improve overtopping estimations with simple overtopping predictors, but it is clear that the optimum roughness factor which should be used in a given overtopping formula requires specific calibration with available experimental data. Using any list of roughness factors, independent of the overtopping predictor can lead to the increase in errors in overtopping prediction. This study focuses attention on estimating the appropriate roughness factor for a given overtopping predictor and experimental database. A change in the overtopping predictor or the experimental data used for calibration may significantly change the optimum roughness factor. 


\begin{tabular}{|c|c|c|c|c|c|}
\hline $\begin{array}{l}\text { Type of armor } \\
2 \mathrm{~L}=\text { double-layer } \\
1 \mathrm{~L}=\text { single-layer }\end{array}$ & 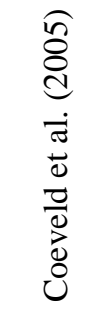 & 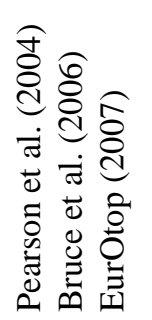 & 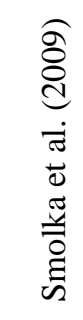 & 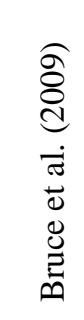 & 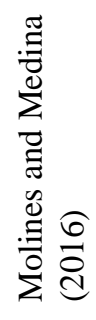 \\
\hline Smooth & 1.00 & 1.00 & - & 1.00 & 0.95 \\
\hline Rock (2L) & 0.50 & 0.40 & - & 0.40 & 0.49 \\
\hline Cube (2L, random) & 0.50 & 0.47 & 0.50 & 0.47 & 0.51 \\
\hline Cube (2L, flat) & - & 0.47 & - & 0.47 & 0.52 \\
\hline Cube (1L, flat) & - & 0.50 & - & 0.49 & 0.55 \\
\hline Antifer (2L) & 0.50 & 0.47 & - & 0.50 & 0.52 \\
\hline Haro (2L) & 0.47 & 0.47 & - & 0.47 & 0.51 \\
\hline Tetrapod (2L) & 0.40 & 0.38 & - & 0.38 & 0.45 \\
\hline Accropode (1L) & 0.49 & 0.46 & - & 0.46 & 0.48 \\
\hline Core-Loc (1L) & 0.47 & 0.44 & - & 0.44 & 0.45 \\
\hline Xbloc (1L) & 0.49 & 0.45 & - & 0.44 & 0.46 \\
\hline Dolos (2L) & 0.43 & 0.43 & - & 0.43 & 0.42 \\
\hline Cubipod (2L) & - & - & 0.44 & - & 0.47 \\
\hline Cubipod (1L) & - & - & 0.46 & - & 0.48 \\
\hline
\end{tabular}

\section{EXPERIMENTAL DATA FROM CLASH DATABASE}

This study focuses on conventional mound breakwaters with crown walls; the cross section is depicted in Fig. 2. This breakwater typology is common for large breakwaters using concrete armor units. Analyzing the CLASH database, 5,995 out of 10,532 tests corresponded to conventional mound breakwaters using the filter: $\cot \alpha_{d}=\cot \alpha_{u}=\cot \alpha, 1.19 \leq \cot \alpha \leq 4, \mathrm{R}_{c}>0$, and $\tan \alpha_{B}=h_{B}=B=0$.

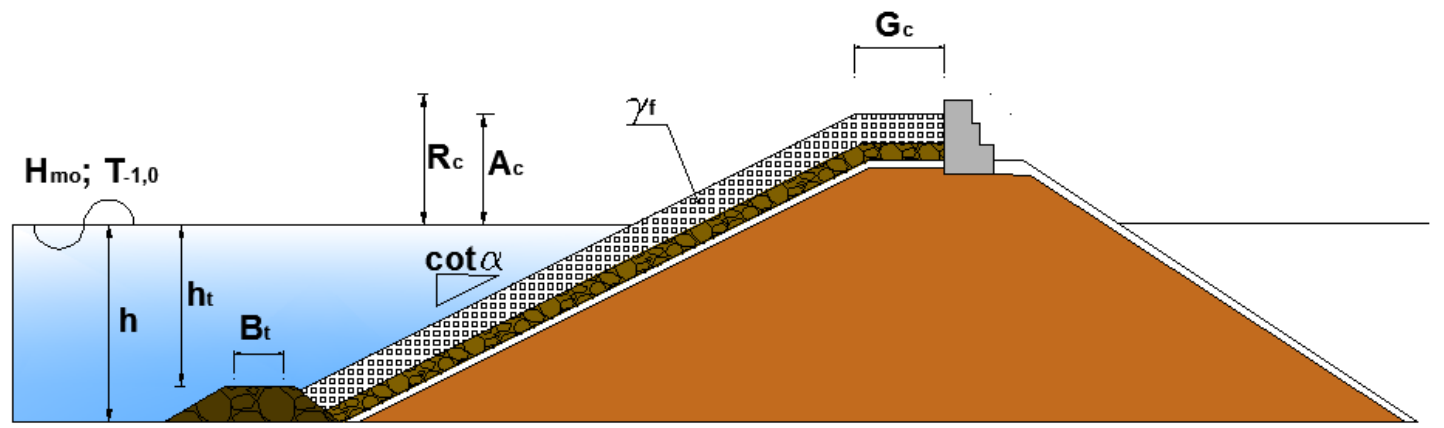

Figure 2. Cross section of a conventional mound breakwater with crown wall.

In order to estimate the appropriate roughness factor for different overtopping predictors, Molines and Medina (2015) suggested using the CLASH database with additional restrictions:

- Data with the best Complexity Factor $(\mathrm{CF}=1) \rightarrow 4,809$ tests

- Data with better Reliability Factors $(\mathrm{RF}=1$ or 2$) \rightarrow 3,649$ tests

- Tests in non-breaking conditions $\left(1.8 H_{m 0 t o e}<0.8 h\right.$ and $\left.I r_{p}=T_{p} / \cot \alpha\left[2 \pi H_{m 0} / g\right]^{0.5}>2\right) \rightarrow 2,444$ tests

- Tests with references and no remarks $\rightarrow 2,193$ tests

- Perpendicular incident wave attack, $\beta=0 \rightarrow 1,752$ tests

- $\mathrm{Q} \geq 10^{-6} \rightarrow 1,501$ tests 
- $0.38 \leq \gamma_{\mathrm{f}} \leq 0.5$ and $\gamma_{\mathrm{f}}=1.00 \rightarrow 1,372$ tests

- Data given by Stewart et al. (2002) were eliminated due to incoherence in the $\gamma_{\mathrm{f}}$ values $\rightarrow 1,219$ tests

- Moreover, 36 tests from the dataset 958 by Pearson et al. (2004) were eliminated because it was not possible to identify the type of armor unit.

- Only 1,183 out of 10,532 tests were considered valid for calibrating roughness factors.

CF and RF are the Complexity and Reliability Factors (see Van Gent et al., 2007). In this study, the same data filters described above were used but only with the most reliable tests $(\mathrm{RF}=1)$. After applying the filter $\mathrm{RF}=1$, only 606 out of 10,532 tests were considered for calibrating roughness factors.

\begin{tabular}{|c|c|c|c|c|c|c|c|c|c|c|c|}
\hline Armor type & $\begin{array}{l}\text { No. data (Molines } \\
\& \text { Medina, 2015) }\end{array}$ & $\begin{array}{r}\text { No. data } \\
\text { (this study) }\end{array}$ & $\begin{array}{l}H_{m 0} \\
{[\mathrm{~m}]}\end{array}$ & $\begin{array}{l}T-1,0 \\
{[\mathrm{~s}]}\end{array}$ & $\begin{array}{l}R_{c} \\
{[\mathrm{~m}]}\end{array}$ & $\begin{array}{l}A_{c} \\
{[\mathrm{~m}]}\end{array}$ & $\begin{array}{l}G_{c} \\
{[\mathrm{~m}]}\end{array}$ & $\cot \alpha$ & $\begin{array}{l}h_{t} \\
{[\mathrm{~m}]}\end{array}$ & $\begin{array}{l}h \\
{[\mathrm{~m}]}\end{array}$ & $\begin{array}{l}B_{t} \\
{[\mathrm{~m}]}\end{array}$ \\
\hline Smooth & 226 & 143 & $\begin{array}{l}0.048- \\
0.192\end{array}$ & $\begin{array}{l}0.782- \\
3.647\end{array}$ & $\begin{array}{l}0.087- \\
0.55\end{array}$ & $\begin{array}{l}0.087- \\
0.55\end{array}$ & 0.000 & $\begin{array}{l}1.19- \\
4.00\end{array}$ & $\begin{array}{l}0.300- \\
0.720\end{array}$ & $\begin{array}{l}0.300- \\
0.720\end{array}$ & 0.000 \\
\hline $\begin{array}{l}\text { Rock } \\
(2 L)\end{array}$ & 555 & 245 & $\begin{array}{l}0.051- \\
0.200\end{array}$ & $\begin{array}{l}0.800- \\
2.560\end{array}$ & $\begin{array}{l}0.062- \\
0.300\end{array}$ & $\begin{array}{l}0.062- \\
0.300\end{array}$ & $\begin{array}{l}0.090- \\
0.200\end{array}$ & $\begin{array}{l}1.50- \\
4.00\end{array}$ & $\begin{array}{l}0.190- \\
0.730\end{array}$ & $\begin{array}{l}0.250- \\
0.730\end{array}$ & $\begin{array}{l}0.000- \\
0.130\end{array}$ \\
\hline $\begin{array}{l}\text { Cubes } \\
\text { (2L, random) }\end{array}$ & 171 & 85 & $\begin{array}{l}0.041- \\
0.136\end{array}$ & $\begin{array}{l}0.747- \\
1.791\end{array}$ & $\begin{array}{l}0.070- \\
0.160\end{array}$ & $\begin{array}{l}0.070- \\
0.160\end{array}$ & $\begin{array}{l}0.089- \\
0.130\end{array}$ & $\begin{array}{l}1.50- \\
2.00\end{array}$ & $\begin{array}{l}0.425- \\
0.722\end{array}$ & $\begin{array}{l}0.455- \\
0.722\end{array}$ & $\begin{array}{l}0.000- \\
0.130\end{array}$ \\
\hline $\begin{array}{l}\text { Antifer } \\
(2 \mathrm{~L})\end{array}$ & 25 & 15 & $\begin{array}{l}0.048- \\
0.115\end{array}$ & $\begin{array}{l}0.791- \\
1.632\end{array}$ & $\begin{array}{l}0.079- \\
0.128\end{array}$ & $\begin{array}{l}0.079- \\
0.128\end{array}$ & 0.099 & 1.50 & $\begin{array}{l}0.676- \\
0.725\end{array}$ & $\begin{array}{l}0.676- \\
0.725\end{array}$ & 0.000 \\
\hline $\begin{array}{l}\text { Tetrapod } \\
\text { (2L) }\end{array}$ & 86 & 10 & $\begin{array}{l}0.079- \\
0.113\end{array}$ & $\begin{array}{l}0.952- \\
1.630\end{array}$ & $\begin{array}{l}0.083- \\
0.135\end{array}$ & $\begin{array}{l}0.083- \\
0.135\end{array}$ & 0.105 & 1.50 & $\begin{array}{l}0.674- \\
0.731\end{array}$ & $\begin{array}{l}0.674- \\
0.731\end{array}$ & 0.000 \\
\hline $\begin{array}{l}\text { Core-Loc } \\
\text { (1L) }\end{array}$ & 27 & 15 & $\begin{array}{l}0.060- \\
0.113\end{array}$ & $\begin{array}{l}0.951- \\
1.639\end{array}$ & $\begin{array}{l}0.086- \\
0.140\end{array}$ & $\begin{array}{l}0.086- \\
0.140\end{array}$ & 0.089 & 1.50 & $\begin{array}{l}0.673- \\
0.727\end{array}$ & $\begin{array}{l}0.673- \\
0.727\end{array}$ & 0.000 \\
\hline
\end{tabular}

Using the specific dataset described above and the methodology given by Molines and Medina (2015), roughness factors were re-calibrated for Eq. [1], Eq. [2], Eq.[3] and the CLASH-NN. The roughness factors depend on the data used for calibration; the new filtering with $\mathrm{RF}=1$ reduced the number of data compared to Molines and Medina (2015) in smooth, rock (2L), Cube (2L, random), Antifer (2L), Tetrapod (2L) and Core-Loc (1L) types of armor. Only the tests listed in Table 2 were used in this study to re-calibrate the roughness factors, as described in the following sections.

\section{ROUGHNESS FACTOR RE-CALIBRATION}

In this study Eq. [1], Eq. [2], Eq.[3] and the CLASH-NN are used with the data given by Table 2 to re-calibrate the roughness factors of different types of armor using the methodology described by Molines and Medina (2015). For a given armor type, 1000 bootstrap resamples of the initial dataset were created and the optimum $\gamma_{\mathrm{f}}$, which minimized the error for each resample, was calculated. Fig. 3 illustrates the error depending on the $\gamma_{\mathrm{f}}$ for five different bootstrap resamples using Eq. [1] with CoreLoc armored breakwaters. It is clear that the optimum $\gamma_{\mathrm{f}}$ depends on the resample.

In this study, the relative Mean Squared Error ( $\mathrm{rMSE}=\mathrm{MSE} / \mathrm{Var}$ ) was used to evaluate the goodness of fit:

$$
r \operatorname{MSE}_{e}(o)=\frac{\operatorname{MSE}_{e}(o)}{\operatorname{Var}(o)}=\frac{\sum_{i=1}^{N}\left(\frac{1}{N}\right)\left(\log Q e_{i}-\log Q o_{i}\right)^{2}}{\operatorname{Var}(\log Q o)}
$$

where $\mathrm{N}=$ total number of data, $\mathrm{i}=$ data index, Qe and Qo are the estimated and target dimensionless mean overtopping discharges using estimator "e" and target data "o". $0 \%<\mathrm{rMSE}<100 \%$ indicates the percentage of variance not explained by the estimator; the lower the rMSE, the better. 


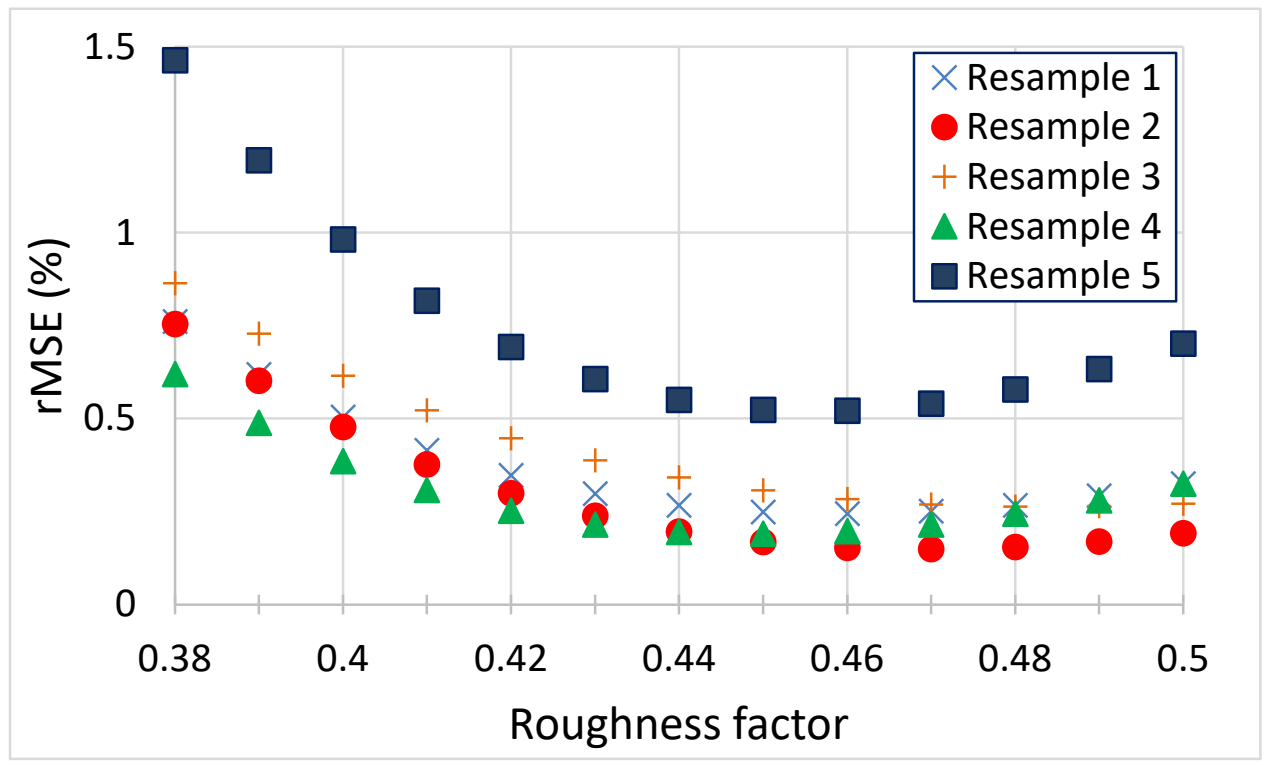

Figure 3. Roughness factor and rMSE for Core-loc (1L) using Eq. [1].

The $10 \%, 50 \%$ and $90 \%$ percentiles $\left(\gamma_{\mathrm{f} 10,}, \gamma_{\mathrm{f} 50,}, \gamma_{\mathrm{f} 90}\right)$ of the 1000 optimum $\gamma_{\mathrm{f}}$ values were calculated. Fig. 4 illustrates the frequency distribution of optimum $\gamma_{\mathrm{f}}$ values using Eq. [1] with Core-Loc armored breakwaters. In this case, $\gamma_{\mathrm{f} 10}=0.44, \gamma_{\mathrm{f} 50}=0.46$ and $\gamma_{\mathrm{f} 90}=0.48$.

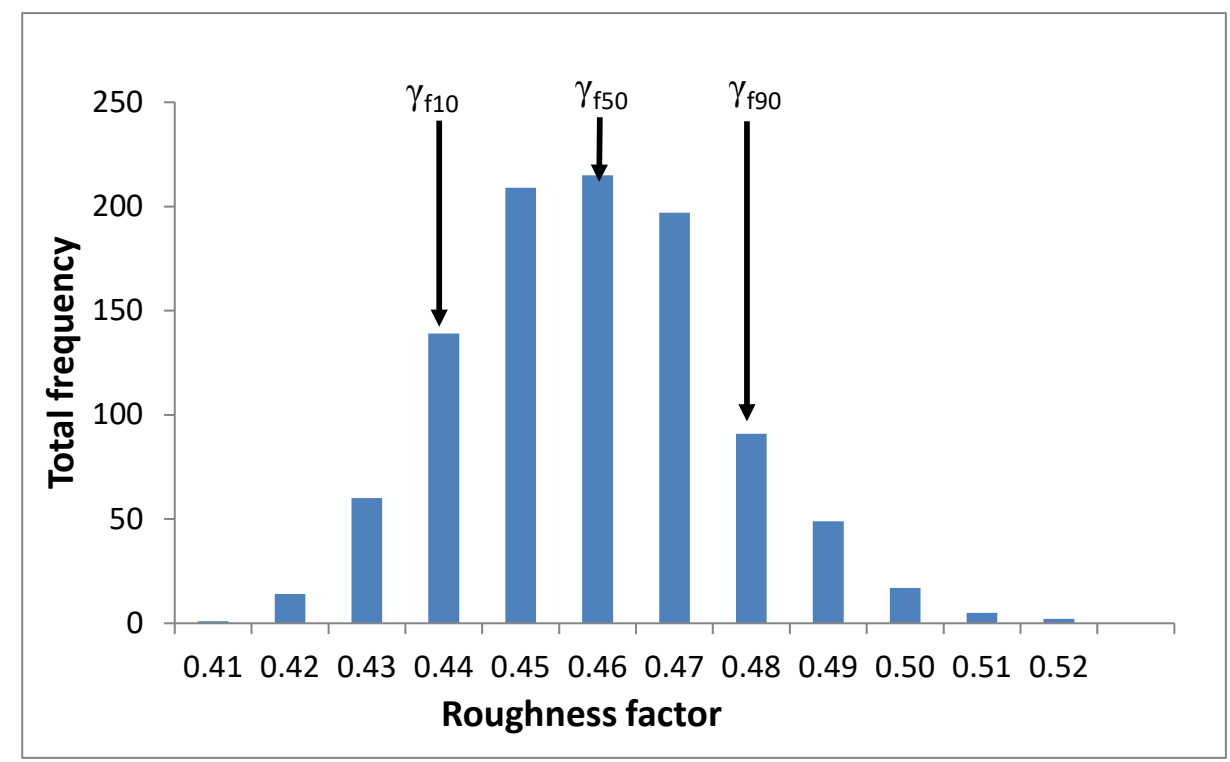

Figure 4. Roughness factor frequency histogram corresponding to Core-Loc (1L) using Eq. [1].

Table 3 compares the roughness factors given by Molines and Medina (2015 and 2016), $\gamma_{\mathrm{fmM}}$, with the re-calibrated roughness factors obtained in this study, $\gamma_{\mathrm{fs}}$. Table 3 shows significant variations in $\gamma_{\mathrm{f} 50}$ values $\left(\gamma_{\mathrm{fs} 50}<\gamma_{\mathrm{f} 10 \mathrm{Mm}}\right.$ or $\left.\gamma_{\mathrm{fs} 50}>\gamma_{\mathrm{fg} 9 \mathrm{MM}}\right)$ for overtopping estimators given by Eq. [1], Eq. [2] and Eq. [3]: up to $10 \%$ (three cases), 15\% (one case) and 7\% (two cases), respectively. On the contrary, the CLASHNN shows insignificant variations in the roughness factor with $\left|\gamma_{\mathrm{f5} 5 \mathrm{Mm}}-\gamma_{\mathrm{fs} 50}\right| \leq 0.01$. CLASH-NN considers a large number of explanatory variables; therefore, the calibrated roughness factors are not as sensitive to the volume of the data used for calibration.

As shown in Table 3, the confidence interval of the re-calibrated roughness factors for Eq. [1], Eq. [2] and Eq. [3], calculated as $\gamma_{\mathrm{fg}}-\gamma_{\mathrm{f} 10}$, were broader than those given by Molines and Medina (2015) for almost all types of armor unit, since those were based on 1,183 tests while the ones in this study were based on 606 tests only. By contrast, the confidence intervals of the re-calibrated roughness 
factors for the CLASH-NN showed insignificant differences compared to those given by Molines and Medina (2015); it is clear that the CLASH-NN are less sensitive to the number of data used to calibrate the $\gamma_{\mathrm{f}}$.

\begin{tabular}{|c|c|c|c|c|c|c|c|c|c|}
\hline \multirow{3}{*}{ Armor type } & \multirow[b]{3}{*}{$\gamma_{\mathrm{f}}$} & \multicolumn{8}{|c|}{ Overtopping estimator } \\
\hline & & \multicolumn{2}{|c|}{$\begin{array}{l}Q_{C L N N}(2007) \\
\text { CLASH-NN }\end{array}$} & \multicolumn{2}{|c|}{$\begin{array}{c}Q_{V M J}(1994) \\
\text { Eq. [1] }\end{array}$} & \multicolumn{2}{|c|}{$\begin{array}{c}Q_{S Z M}(2009) \\
\text { Eq. [2] }\end{array}$} & \multicolumn{2}{|c|}{$\begin{array}{c}Q_{M M}(2016) \\
\text { Eq. [3] }\end{array}$} \\
\hline & & $\gamma_{\mathrm{fMM}}$ & $\gamma_{\mathrm{fs}}$ & $\gamma_{\mathrm{fMM}}$ & $\gamma_{\mathrm{fs}}$ & $\gamma_{\mathrm{fMM}}$ & $\gamma_{\mathrm{fs}}$ & $\gamma_{\mathrm{fMM}}$ & $\gamma_{\mathrm{fs}}$ \\
\hline \multirow[t]{3}{*}{ Smooth } & $\gamma_{\mathrm{f} 10}$ & 0.99 & 0.99 & 1.02 & 1.01 & 1.18 & 1.15 & 0.94 & 0.93 \\
\hline & $\gamma_{\mathrm{f} 50}$ & 1.00 & 1.00 & 1.03 & 1.04 & 1.21 & 1.18 & 0.95 & 0.94 \\
\hline & $\gamma_{f 90}$ & 1.00 & 1.00 & 1.05 & 1.06 & 1.24 & 1.22 & 0.96 & 0.96 \\
\hline \multirow[t]{3}{*}{ Rock } & $\gamma_{\mathrm{f} 10}$ & 0.48 & 0.49 & 0.45 & 0.40 & 0.43 & 0.43 & 0.48 & 0.48 \\
\hline & $\gamma_{\mathrm{f} 50}$ & 0.49 & 0.49 & 0.45 & 0.41 & 0.44 & 0.44 & 0.49 & 0.49 \\
\hline & $\gamma_{\mathrm{f} 90}$ & 0.50 & 0.50 & 0.46 & 0.41 & 0.44 & 0.44 & 0.49 & 0.49 \\
\hline \multirow{3}{*}{$\begin{array}{l}\text { Cube } \\
\text { (2L, random) }\end{array}$} & $\gamma_{\mathrm{f} 10}$ & 0.52 & 0.52 & 0.44 & 0.41 & 0.43 & 0.44 & 0.50 & 0.49 \\
\hline & $\gamma_{\mathrm{f} 50}$ & 0.53 & 0.53 & 0.45 & 0.42 & 0.44 & 0.44 & 0.51 & 0.50 \\
\hline & $\gamma_{\mathrm{f} 90}$ & 0.53 & 0.53 & 0.46 & 0.43 & 0.45 & 0.45 & 0.51 & 0.50 \\
\hline \multirow{3}{*}{$\begin{array}{l}\text { Antifer } \\
\text { (2L) }\end{array}$} & $\gamma_{\mathrm{f} 10}$ & 0.51 & 0.52 & 0.48 & 0.50 & 0.48 & 0.50 & 0.50 & 0.53 \\
\hline & $\gamma_{\mathrm{f} 50}$ & 0.52 & 0.53 & 0.50 & 0.52 & 0.51 & 0.54 & 0.52 & 0.55 \\
\hline & $\gamma_{f 90}$ & 0.53 & 0.55 & 0.52 & 0.56 & 0.54 & 0.58 & 0.54 & 0.57 \\
\hline \multirow[t]{3}{*}{ Tetrapod } & $\gamma_{\mathrm{f} 10}$ & 0.41 & 0.40 & 0.42 & 0.39 & 0.38 & 0.44 & 0.44 & 0.40 \\
\hline & $\gamma_{\mathrm{f} 50}$ & 0.42 & 0.41 & 0.43 & 0.41 & 0.39 & 0.46 & 0.45 & 0.42 \\
\hline & $\gamma_{\mathrm{f} 90}$ & 0.43 & 0.42 & 0.43 & 0.43 & 0.40 & 0.49 & 0.46 & 0.43 \\
\hline \multirow[t]{3}{*}{ Core-Loc (1L) } & $\gamma_{\mathrm{f} 10}$ & 0.45 & 0.45 & 0.44 & 0.44 & 0.44 & 0.44 & 0.44 & 0.44 \\
\hline & $\gamma_{\mathrm{f} 50}$ & 0.46 & 0.46 & 0.46 & 0.46 & 0.46 & 0.46 & 0.45 & 0.46 \\
\hline & $\gamma_{\mathrm{f} 90}$ & 0.47 & 0.46 & 0.47 & 0.48 & 0.48 & 0.49 & 0.48 & 0.47 \\
\hline
\end{tabular}

\section{CONCLUSIONS}

The roughness factor is dependent not only on the type of armor, number of layers and placement method, but also on the overtopping estimator and database used for calibration. In this study, the methodology to calibrate the $\gamma_{\mathrm{f}}$ given by Molines and Medina (2015) is applied to the CLASH database considering more restrictive data filters for the most reliable data only (606 instead of 1,183 tests). The $\gamma_{\mathrm{f}}$ is re-calibrated for smooth, rock (2Layer), Cube (2Layer, random), Antifer (2Layer), Tetrapod (2Layer) and Core-loc (1Layer) types of armor using Eq. [1], Eq. [2], Eq. [3] and the CLASH-NN.

For a given overtopping estimator and type of armor, the optimum $\gamma_{\mathrm{f}}$ is calculated for 1000 bootstrap resamples and the $10 \%, 50 \%$ and $90 \%$ percentiles of the optimum $\gamma_{\mathrm{f}}$ histogram are obtained $\left(\gamma_{\mathrm{f} 10}, \gamma_{\mathrm{f} 50}, \gamma_{\mathrm{f} 90}\right)$. Considering the explicit overtopping predictors, Eqs. [1] to [3], significant variations in $\gamma_{\mathrm{f5}}$ are obtained in some cases. By contrast, when considering the CLASH-NN overtopping predictor, insignificant variations are observed. It is clear that CLASH-NN, which is a multi-parametric black-box overtopping predictor with a very large number of input parameters, is much less sensitive to the volume of data used to calibrate the roughness factor. Simple explicit overtopping estimators are more sensitive to the volume of data for calibration because they are highly dependent on the roughness factor to absorb the information not explicitly considered by a fewer explanatory input variables.

Considering Eqs. [1] to [3], the confidence interval width of the re-calibrated roughness factors in this study, $\gamma_{\mathrm{fs} 90}-\gamma_{\mathrm{fs} 10}$, is broader than that obtained by Molines and Medina (2015). Therefore, Eqs. [1] to 
[3] are much more sensitive than the CLASH-NN to the number of data used to calibrate the optimum roughness factor $\gamma_{\mathrm{f}}$, both in terms of the median value and confidence interval. The roughness factor, $\gamma_{\mathrm{f}}$, should never be assumed as a constant value dependent on the type of armoring, but rather as a parameter which depends as well on the overtopping predictor and the experimental data used for calibration.

\section{ACKNOWLEDGMENTS}

The authors are grateful for financial support from Spanish Ministerio de Economía y Competitividad (Grant BIA2015-70436-R). The authors also thank Debra Westall for revising the manuscript.

\section{REFERENCES}

Bruce, T., Van der Meer, J.W., Franco, L., and J.M. Pearson. 2006. A comparison of overtopping performance of different rubble mound breakwater armour. Proceedings $30^{\text {th }}$ International Conference on Coastal Engineering. World Scientific, Vol. 5, 4567-4579.

Bruce, T., Van der Meer, J.W., Franco, L., and J.M. Pearson. 2009. Overtopping performance of different armour units for rubble mound breakwaters. Coastal Engineering 56 (2), 166-179.

Coeveld, E.M., Van Gent, M.R.A., and B. Pozueta. 2005. Neural Network, Manual NN_OVERTOPPING 2.0, CLASH: Workpackage 8, 38 pp.

Deltares. 2017. Overtopping neural network. [on line] Deltares. Available at: https://www.deltares.nl/en/software/overtopping-neural-network/ [Accesed 25 Jan. 2017].

EurOtop, 2007. Wave Overtopping of Sea Defences and Related Structures: Assessment Manual (EurOtop Manual). Pullen, T., Allsop, N.W.H., Bruce, T., Kortenhaus, A., Schüttrumpf, H., and Van der Meer, J.W. Environment Agency, UK/ENW Expertise Netwerk Waterkeren, NL/KFKI Kuratorium für Forschung im Küsteningenieurwesen, Germany, 178 pp.

Molines, J., and J.R. Medina. 2015. Calibration of overtopping roughness factors for concrete armor units in non-breaking conditions using CLASH database. Coastal Engineering 96 (2015), 62-70.

Molines, J., and J.R. Medina. 2016. Explicit wave overtopping formula for mound breakwaters with crown walls using CLASH neural network-derived data. Journal of Waterway, Port, Coastal and Ocean Engineering, 142 (3), 04015024, 13 pp.

Pearson, J., Bruce, T., Franco, L., Van der Meer, J., Falzacappa, M., and R. Molino. 2004. Report on additional tests, part B: Standard tests for roughness factors, CLASH WP4 report, University of Edinburgh, UK, 53 pp.

Smolka, E., Zarranz, G., and J.R. Medina. 2009. Estudio Experimental del Rebase de un Dique en Talud de Cubípodos. Libro de las X Jornadas Españolas de Costas y Puertos, Universidad de Cantabria, 803-809 (in Spanish).

Stewart, T.P., Newberry, S.D., Simm, J.D., and J.P. Latham. 2002. The hydraulic performance of tightly packed rock armour layers. Proceedings $28^{\text {th }}$ International Conference on Coastal Engineering, World Scientific, Vol. 2, 1449-1471.

Van der Meer, J.W., and J.P.F.M. Janssen. 1994. Wave Run-Up and Wave Overtopping at Dikes, Delft Hydraulics No. 485.

Van der Meer, J.W., and T. Bruce. 2014. New Physical Insights and Design Formulas on Wave Overtopping at Sloping and Vertical Structures. Journal of Waterway, Port, Coastal and Ocean Engineering, 140 (6), 04014025, 18 pp.

Van Gent, M.R.A., Van den Boogaard, H.F.P., Pozueta, B., and J.R. Medina. 2007. Neural network modelling of wave overtopping at coastal structures. Coastal Engineering 54 (8), 586-593. 